\title{
Digital Animasi 2 Dimensi Dengan Metode Cell Shadding Dan Rigging Bone Studi Kasus : Legenda Gunung Tugel
}

\author{
Fendi Aji Purnomo \\ Fakultas MIPA, Program Studi D3 Teknik Informatika \\ Universitas Sebelas Maret \\ Email: fendi_aji@mipa.uns.ac.id
}

\author{
Eko Harry P, Agus Purnomo, Ahzan Saiful Huda, Ady Setyo Nugroho, Aditya Chrisna \\ Mahendra \\ Fakultas MIPA, Program Studi D3 Teknik Informatika \\ Universitas Sebelas Maret \\ Email: eko.harry@gmail.com, ahzansaifulhuda@gmail.com,guspur@mipa.uns.ac.id
}

\begin{abstract}
ABSTRAK
Kebudayaan Indonesia dewasa kini semakin berkurang. Masyarakat Indonesia, semakin terpengaruh oleh kebudayaan luar melalui perkembangan teknologi yang semakin canggih. Salah satunya adalah kebudayaan berupa cerita legenda yang berkembang di daerah masing - masing, sehingga menjadi ironis ketika anak zaman sekarang tidak mengetahui bahkan tidak peduli akan budayanya sendiri. Salah satu cerita legenda yang berkembang yaitu "Gunung Tugel" yang berasal dari daerah boyolali, yang kental menceritakan tentang kearifan dan keramahan budaya.

Media edukasi yang saat ini digemari oleh masyarakat umum salah satunya adalah film animasi. Film animasi "Legenda Gunung Tugel" dibuat dengan metode rigging bone dan cell shading dengan model 2 Dimensi, yang memiliki durasi waktu 18 menit 54 detik, dengan spesikasi ekstensi .mp4, resolusi video 1280x720, dan frame rate $24 \mathrm{fps}$. Dalam pembuatan film tersebut, menggunakan software Moho Anime Studio untuk membuat animasi, kemudian Adobe Illustrator, CorelDraw, dan Photoshop, untuk membuat modelling, serta Adobe After Effect untuk proses editing video.

Berdasarkan pengkajian kuisioner yang telah dilakukan terhadap 41 responden, dapat diketahui bahwa sebanyak 79\% menilai bahwa film animasi "Legenda Gunung Tugel" bernilai baik dalam aspek desain model karakter. Adapun untuk aspek yang lainnya, seperti audio sebanyak $85 \%$ menarik. Aspek visual effect, sebanyak 76\% menarik, dan aspek environment bernilai baik sebesar $77 \%$
\end{abstract}

Kata kunci: Kebudayaan, Legenda Gunung Tugel, Animasi 2D, rigging bone, cell shadding

\section{ABSTRACT}

Mature Indonesian culture is now diminishing. Indonesian society, increasingly popular by the outside culture through the development of increasingly sophisticated technology. One is the story of a growing legend in their respective regions, so it becomes ironic as children today are uncertain of not caring about their own culture. One of the growing legend stories is "Gunung Tugel" which originated from Boyolali area, which tells about wisdom and culture.

Media education currently popular by the public one of them is the animated film. The animated film "Legend of Mount Tugel" is built using the 2 Dimension method, which has a duration of 20 minutes, with the specification of .mp4 extension, $1280 \times 720$ video resolution, and frame rate of $24 \mathrm{fps}$. In making the film, use Moho Anime Studio software 
to create animations, then Adobe Illustrator, CorelDraw, and Photoshop, for modeling, and Adobe After Effect for video editing process.

Based on a questionnaire assessment that has been conducted on 41 respondents, it can be seen that as much as $79 \%$ considered that the animated film "Legend of Gunung Tugel" is good value in the character design aspect of the character. As for other aspects, such as audio as much as $85 \%$ interesting. Aspects of visual effects, as much as $76 \%$ interesting, and environmental aspects of good value of $77 \%$

Keywords: Culture, Legend of Gunung Tugel, 2D Animation, rigging bone, cell shadding

\section{PENDAHULUAN}

Kebudayaan Indonesia saat ini semakin berkurang peminatya. Masyarakat Indonesia semakin terpengaruh oleh kebudayaan luar melalui perkembangan teknologi yang semakin maju. Apabila kita menanyakan pada anak zaman sekarang, mengenai legenda dan cerita tradisional yang ada di daerahnya sendiri, mereka akan bingung karena tidak pernah melihat dan mendengar tentang legenda atau cerita tradisional tersebut.

Terdapat beberapa peneliti yang telah mengembangkan produk film animasi dalam tujuan sebagai media edukasi, diantaranya yaitu Barnas Danu Adinata [1] dengan judul animasi "Legenda Roro Jonggrang". Animasi ini mengangkat cerita yang berasal dari daerah Yogyakarta tentang kehidupan Roro Jonggrang yang sangat berkaitan erat dengan asal - usul terbentuknya Candi Prambanan. Dalam perancangan dan pembuatan animasi ini menggunakan software utama Blender. Cerita "Legenda Roro Jonggrang" mengangkat 5 tokoh utama diantaranya adalah Roro Jonggrang, Bandung Bondowoso, Prabu Boko, Mbok dan seorang prajurit.

Peneliti kedua yaitu Veronica Wahyu K [2] dengan judul animasi "Legenda Danau Toba". Sesuai dengan judulnya penulis mengangkat cerita yang berasal dari daerah Sumatera Utara tentang asal - usul terbentuknya Danau Toba. Dalam perancangan dan pembuatan animasi ini menggunakan software Adobe Flash CS3. Cerita "Legenda Danau Toba" melibatkan 3 tokoh utama diataranya Petani (Toba), Istri Toba (Putri), dan Anak Toba (Samosir).

Peneliti ketiga yaitu Chabib Syafrudin dan Wahyu Pujiono [3] dengan judul "Perancangan Video Motivasi Animasi 2D untuk Buku Terlaris di Dunia "Who Moved My Cheese?"'. Animasi ini bertujuan untuk membagikan video dalam bentuk 2D yang berisi motivasi berdasarkan kisah fiktif buku terlaris di dunia “Who Moved My Cheese?". Animasi ini menggunakan software Adobe Flash Profesional CC. dalam animasi ini terdapat 4 tokoh, masing - masing 2 tikus (bernama Sniff dan Scurry) dan 2 kurcaci (bernama Hem dan Haw).

Peneliti keempat yaitu Jonathan Fukaren [4] dengan judul "Pembuatan Film Animasi Pendek "Dahsyatnya Sedekah" Berbasis Multimedia Menggunakan Teknik 2D Hybrid Animation dengan Pemanfaatan Graphic". Animasi ini bertujuan untuk media edukasi dalam pembelajaran guru agama ataupun orang tua dalam memberikan pelajaran kepada anak untuk bersedekah. Dalam perancangan dan pembuatan animasi ini melibatkan tokoh utama bernama Ahsan dan disertai dengan 7 tokoh pendukung.

Peneliti kelima yaitu Dani Kuswan [5] dengan judul Tugas Akhir "Animasi 2D 3 Menit Belajar IImu Pengetahuan Umum". Animasi ini bertujuan sebagai media pembelajaran khususnya untuk anak - anak dalam belajar IImu Pengetahuan Umum. Teknik animasi menggunakan Motion Graphic. Pada animasi ini terdapat 4 Tokoh utama diantaranya paman penyihir, Nemo, Pingu, dan Ding Dong

Salah satu cerita legenda yang berkembang di kalangan masyarakat adalah Legenda Gunung Tugel, yang berasal dari daerah Boyolali, Jawa Tengah. Gunung Tugel merupakan sebuah tempat ziarah yang ada di wilayah Boyolali, karena terdapat makam dari Ki Hageng Singoprono, yang merupakan tokoh dari daerah tersebut. Beliau merupakan anak tunggal dari Ki Wongsoprono II dan memiliki istri bernama Nyai 
Singoprono. Gunung Tugel terletak sekitar $12 \mathrm{~km}$ dari pusat Kota Boyolali dan berada di ketinggian 97,5 meter dari permukaan laut dengan luas sekitar $700 \mathrm{~m} 2$, sehingga diperlukan 100 anak tangga yang diperlukan untuk sampai ke makam Ki Singoprono.

Secara umum jenis-jenis film animasi telah berkembang sesuai dengan kemajuan teknologi yang ada sehingga memunculkan jenis animasi atau teknik pembuatan animasi yang baru. Jenis-jenis film animasi menurut Zaharuddin G [6] yang sering diproduksi antara lain Animasi 2D, jenis animasi ini lebih dikenal dengan sebutan film kartun, seperti Lion King, Doraemon, Crayon Sinchan, Naruto, dan lain sebagainya.Teknik penggarapannya dengan menggunakan teknik animasi sel (celtechnique), penggambaran langsung pada film atau secara digital. Animasi 3D, pengembangan dari animasi 2D yang muncul akibat perkembangan teknologi yang sangat pesat. Kelebihan animasi 3D adalah dapat memperlihatkan kesan hidup dan nyata pada objeknya. Animasi tanah liat (clay animation), animasi yang dibuat dengan menggunakan tanah liat khusus kemudian dianimasikan dengan teknik stopmotion picture .

Jenis-jenis film animasi tersebut di atas dalam perkembangannya dapat dikombinasikan antara satu sama lainnya tergantung kebutuhan dari sang animator. Penggabungan ini dapat menciptakan suatu karya animasi yang lebih unik. Animasi yang menggunakan teknik rigging yaitu animasi yang dalam pembuatannya menggunakan sistem kerangka atau sistem skeletal [7]. Sistem kerangka tersebut diletakkan pada bagian-bagian anggota gerak sebuah karakter, sehingga dapat digerak-gerakkan seperti gerak persendian pada anggota gerak.

Pesatnya perkembangan teknologi dibidang informasi membuat rasa kepedulian masyarakat khususnya generasi muda terhadap budaya lokal semakin menurun. Hal ini disebabkan karena masyarakat lebih memilih mengikuti arus budaya asing daripada bangga terhadap budaya lokal, misalnya seperti melestarikan cerita legenda Gunung Tugel. Sehingga dapat dikatakan bahwa hal tersebut merupakan faktor penyebab cerita legenda Gunung Tugel kurang dikenal oleh masyarakat umum diluar Boyolali, karena proses publikasi yang kurang baik dari masyarakat daerah tersebut.

Dalam penelitian ini akan dikembangkan jenis animasi $2 \mathrm{D}$ dengan metode rigging bone dan shell animation dalam mengankat cerita edukasi Legenda gunung Tugel. Judul tersebut merupakan film yang unik dari kebudayaan lokal yaitu dari Kabupaten Boyolali. Peninggalan makam Ki Hageng Singoprono masih terawat dengan baik di daerah Simo, sehingga untuk melestarikan kearifan beliau dan sebagai media edukasi perlu dikembangkan film.

\section{METODOLOGI PENELITIAN}

Dalam proses pembuatan film animasi Legenda Gunung Tugel menggunakan metode pembuatan yang dikembangkan oleh Villamil-Molina (1997). Adapun tahapan tahapannya sebagai berikut :

\subsection{Development}

Pada tahap ini konsep produk multimedia mulai disusun dan dibentuk berdasarkan ide - ide yang sudah ada. Pada tahap ini, penulis melakukan 3 teknik dalam mengumpulkan data untuk pembuatan film animasi legenda Gunung Tugel.

a. Studi pustaka, yaitu pengumpulan data seputar sejarah Gunung Tugel yang bersumber kepada buku, majalah, internet, dan informasi lainnya sebagai tinjauan pustaka yang berkaitan dengan penelitian ini.

b. Observasi, yaitu kegiatan mengunjungi tempat Gunung Tugel secara langsung dengan tujuan untuk mendapatkan informasi yang lebih akurat.

c. Wawancara, yaitu pengumpulan data yang dilakukan dengan cara tanya jawab dengan penanggung jawab tempat Gunung Tugel, hal ini dilakukan untuk mendapatkan informasi seputar sejarah Gunung 


\subsection{Preproduction}

Pada tahapan kedua ini, melakukan persiapan untuk mengerjakan produk multimedia. Tahapan ini merupakan tahapan yang penting dalam pembuatan film animasi Legenda Gunung Tugel. Perancangan meliputi pembuatan alur cerita, naskah cerita, dan storyboard, pembuatan desain tokoh dan background yang digunakan dalam setiap scene. Selanjutnya dilakukan pengisian suara (dubbing) untuk setiap tokoh dalam cerita. Dalam tahap ini pula ditentukan output dari film animasi yang dibuat, meliputi format, resolusi, framerate, dan durasi film.

\subsection{Production}

Pada tahap ketiga ini, proses produksi animasi mulai dikerjakan, dilakukannya proses penganimasian terhadap tokoh (modeling) dan background yang sebelumnya telah dibuat. Pada tahap ini juga proses dubbing yang telah dilakukan sebelumnya, disisipkan dalam proses penganimasian dengan menggunakan software Moho Anime Studio.

\subsection{Postproduction}

Pada tahap keempat ini, produk multimedia yang sudah dibuat memasuki tahapan pengujian. Pada tahap pengujian dilakukan dengan metode kuisoner, dengan objek penilaian adalah trailer dari film animasi Legenda Gunung Tugel, sehingga penonton dapat menilai langsung sesuai dengan poin penilaian yang terdapat kuisioner tersebut.

\subsection{Delivery}

Tahap ini merupakan tahap akhir dari pengembangan produk multimedia. Pada tahap delivery film animasi Legenda Gunung Tugel dilakukan dengan cara memamerkan pada acara expo D3 Teknik Informatika UNS dan mengunggah film tersebut ke internet.

\section{HASIL DAN PEMBAHASAN}

\subsection{Sinopsis Legenda Gunung Tugel}

Sinopsis film animasi Legenda Gunung Tugel adalah Cerita "Legenda Gunung Tugel" berasal dari derah Boyolali, Jawa Tengah. Cerita ini menceritakan tentang Ki Singoprono dan Ki Rogo Runting yang sudah bersahabat sejak kecil. Ki Singoprono sejak kecil selalu ditanami sifat - sifat kebaikan oleh ayahnya yang bernama Ki Wongsoprono, sehingga ketika beliau dewasa, sifat kebaikan selalu dilakukan sehingga masyarakat sangat menghormatinya. Ki Rogo Runting tumbuh menjadi seseorang yang sakti mandraguna. Beliau yang awalnya bersahabat dengan Ki Singoprono seketika berubah menjadi kebencian ketika rasa iri hati muncul di benak Ki Rogo Runting. Beliau tidak terima kalau Ki Singoprono begitu disegani, dihormati, dan dicintai oleh semua masyarakat, dan Ki Rogo Runting merasa kalau dirinya lebih hebat dari Ki Singoprono. Karena hatinya sudah dikuasai oleh kebencian, Ki Rogo Runting akhirnya mencari cara untuk menghancurkan Ki Singoprono. Beliau memanah gunung dekat rumah Ki Singoprono dengan tujuan daerah yang disekitar gunung juga ikut hancur termasuk Ki Singoprono. Ketika Ki Rogrunting memanah gunung tersebut untuk kedua kalinya Ki Singoprono membalikkan panah tersebut dengan centong sakti, yang membuat tempat Ki Rogo Runting memanah (Gunung Madu) hancur termasuk Ki Rogo Runting.

\subsection{Storyboard}

Pembuatan stroryboard dimaksudkan sebagai acuan dalam pembuatan animasi cerita "Legenda Gunung Tugel". Stroryboard menggambarkan kondisi dari setiap scene, yang meliputi tokoh karakter, konsep kamera, property yang digunakan, backsound, hingga panjang waktu dari setiap scene tersebut. Berikut adalah storyboard dari cerita "Legenda Gunung Tugel"disajikan pada Tabel 1. 
Tabel 1. Storyboard Legenda Gunung Tugel

\begin{tabular}{|c|c|c|c|}
\hline Scene & Ilustrasi & Waktu & Keterangan \\
\hline 1 & & $\begin{array}{l}00.01- \\
00.15\end{array}$ & $\begin{array}{l}\text { 1. Kamera zoom in ke arah } \\
\text { tokoh Ki Singoprono } \\
\text { kecil dan Ki Rogorunting } \\
\text { kecil secara bergantian } \\
\text { 2. Musik background } \\
\text { tenang disertai suara } \\
\text { teriakan seperti sedang } \\
\text { latihan silat }\end{array}$ \\
\hline
\end{tabular}

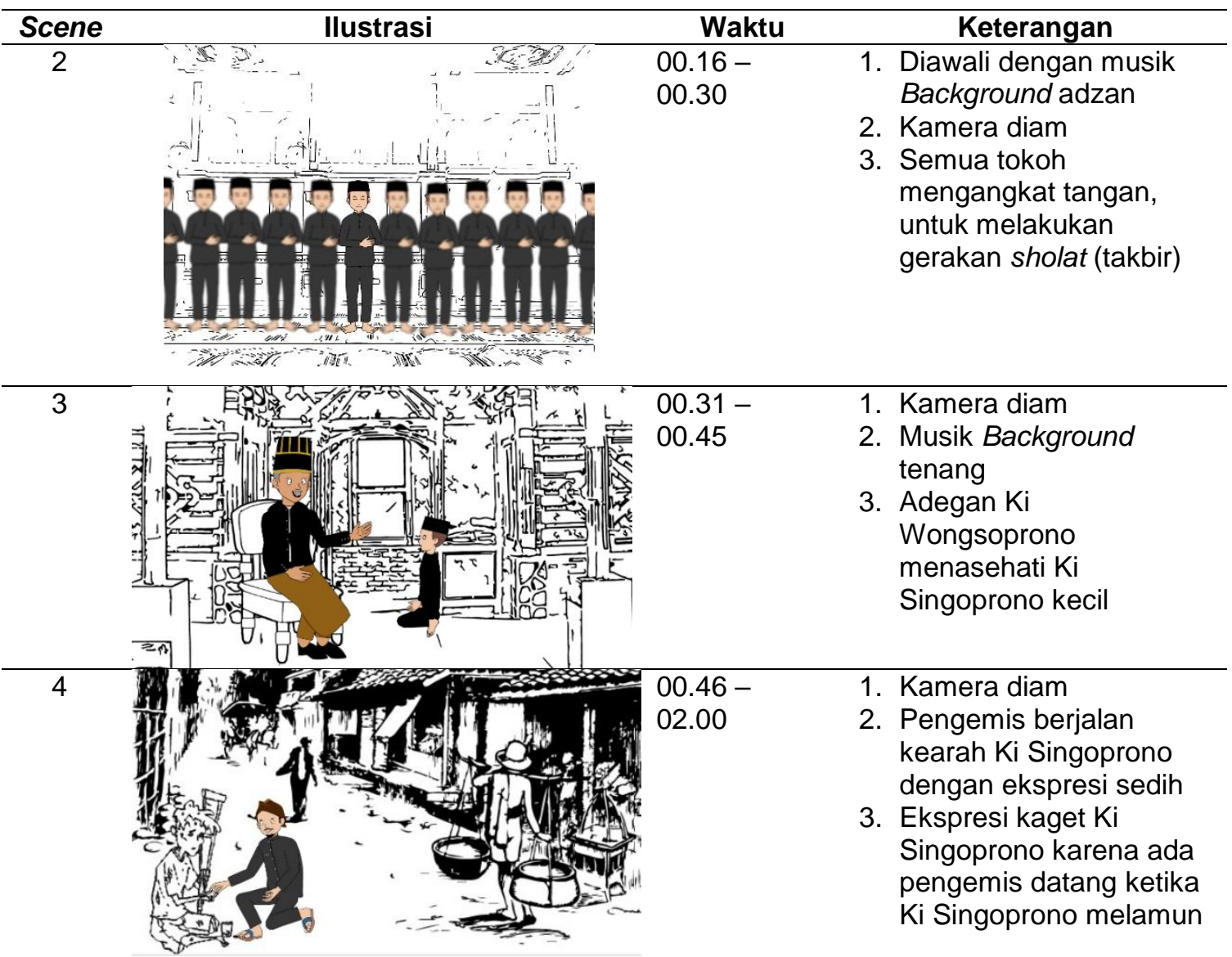




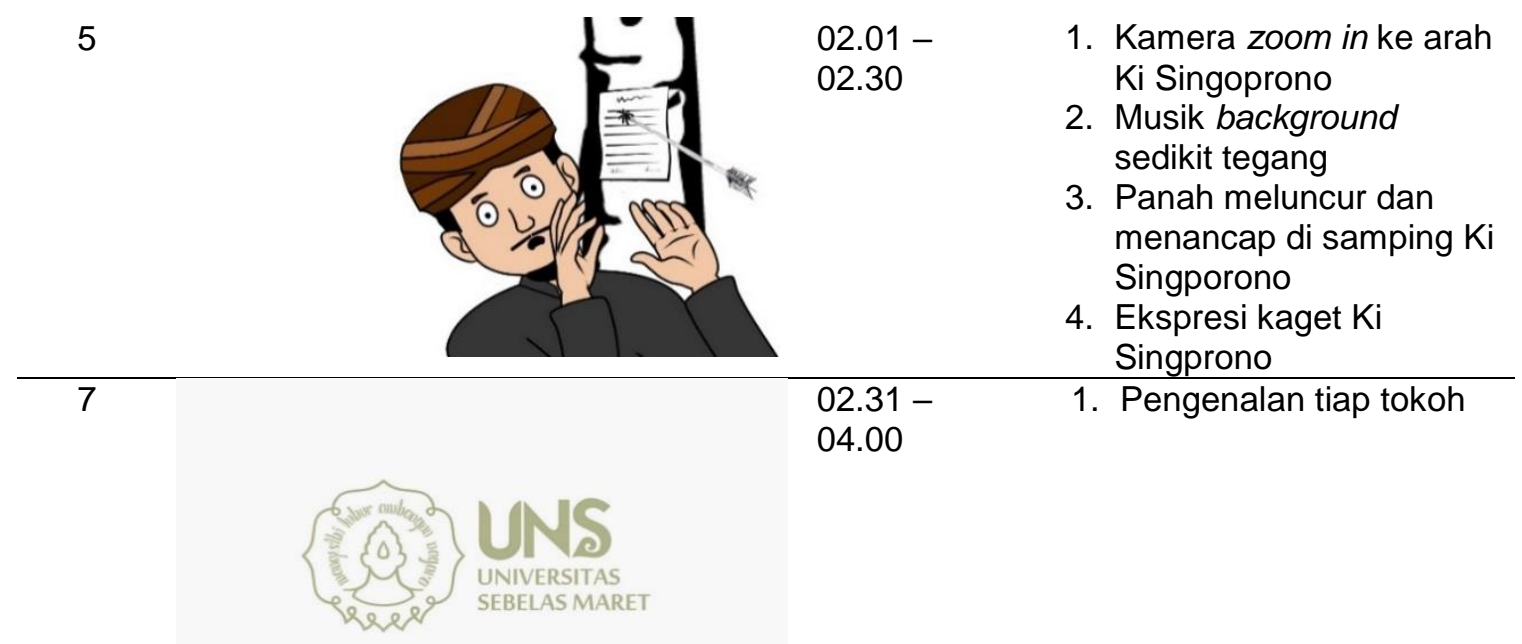

\begin{tabular}{ll}
\hline Scene & Kaktu
\end{tabular}


4. Efek suara hentakan kaki seperti berjalan

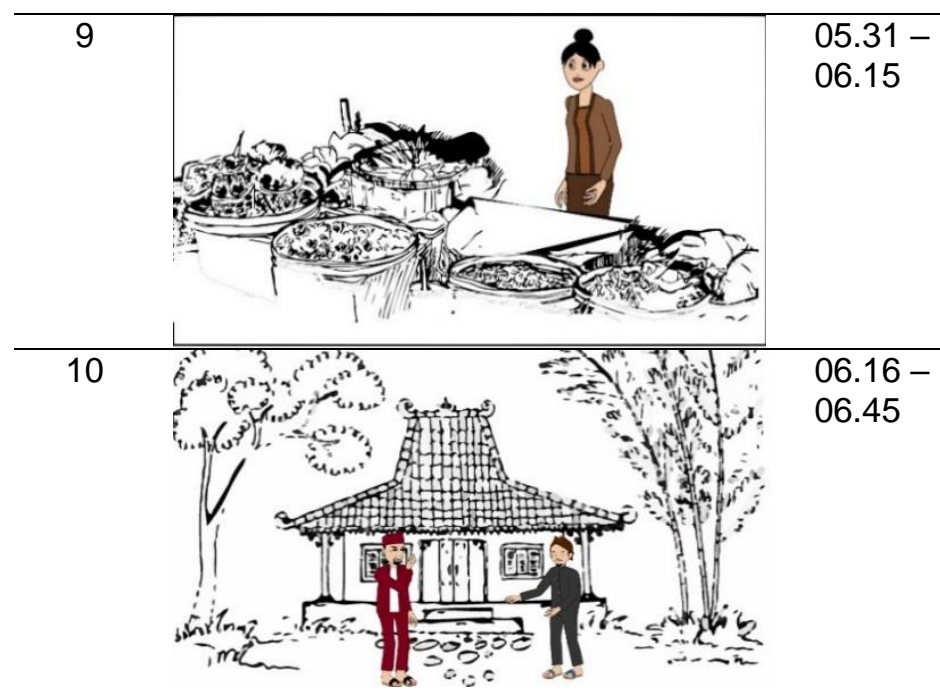

1. Kamera diam

2. Musik background tenang disertai kicauan burung karena suasana masih pagi

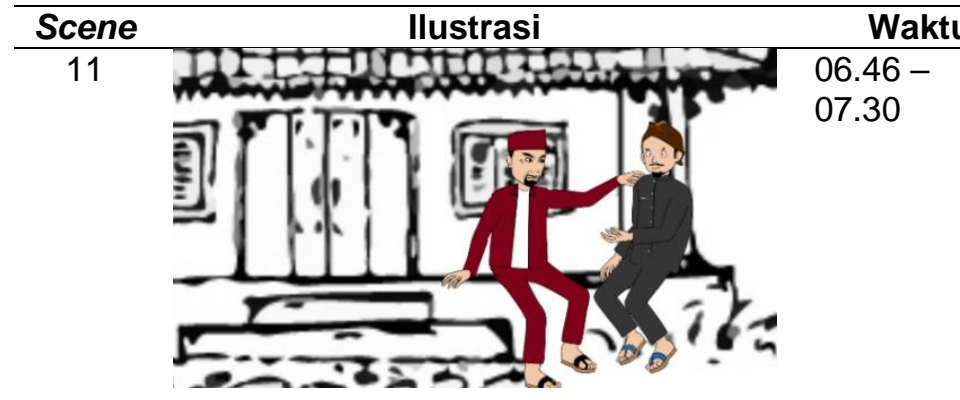

$07.31-$ 08.30

1. Musik background ceria

2. Ekspresi terkejut Ki Singoprono melihat Ki Rogorunting bertamu ke rumahnya

3. Kamera diam

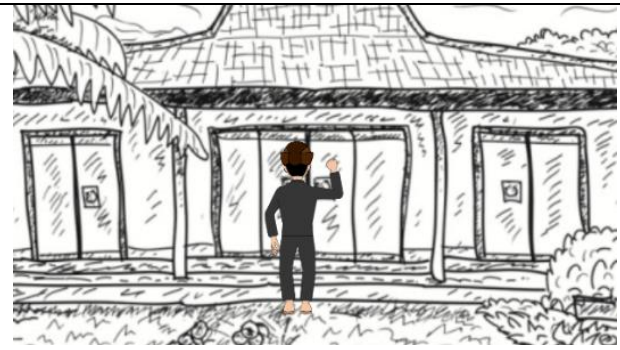

Keterangan

1. Kamera zoom in

2. Ki Singoprono berjalan beriringan kearah saung

3. Efek suara hentakan kaki seperti berjalan

4. Musik background ceria karena menggambarkan pertemuan sahabat yang lama tidak bertemu

1. Musik background agak tegang karena cuaca panas siang hari

2. Kamera diam

3. Suara memanggil Ki Singoprono 
13

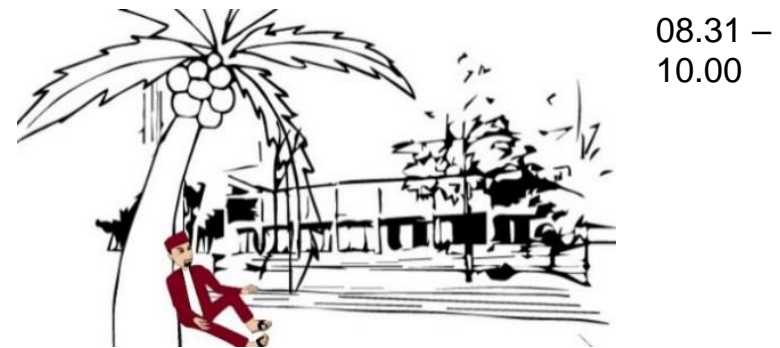

1. Kamera zoom in kemudian zoom out

2. Ekspresi melamun kemudian terkejut ketiak Ki Rogorunting melihat kedatangan $\mathrm{Ki}$ Singoprono di kebunnya

3. Musik background tenang disertai suara angina kecil karena suasananya berada di kebun
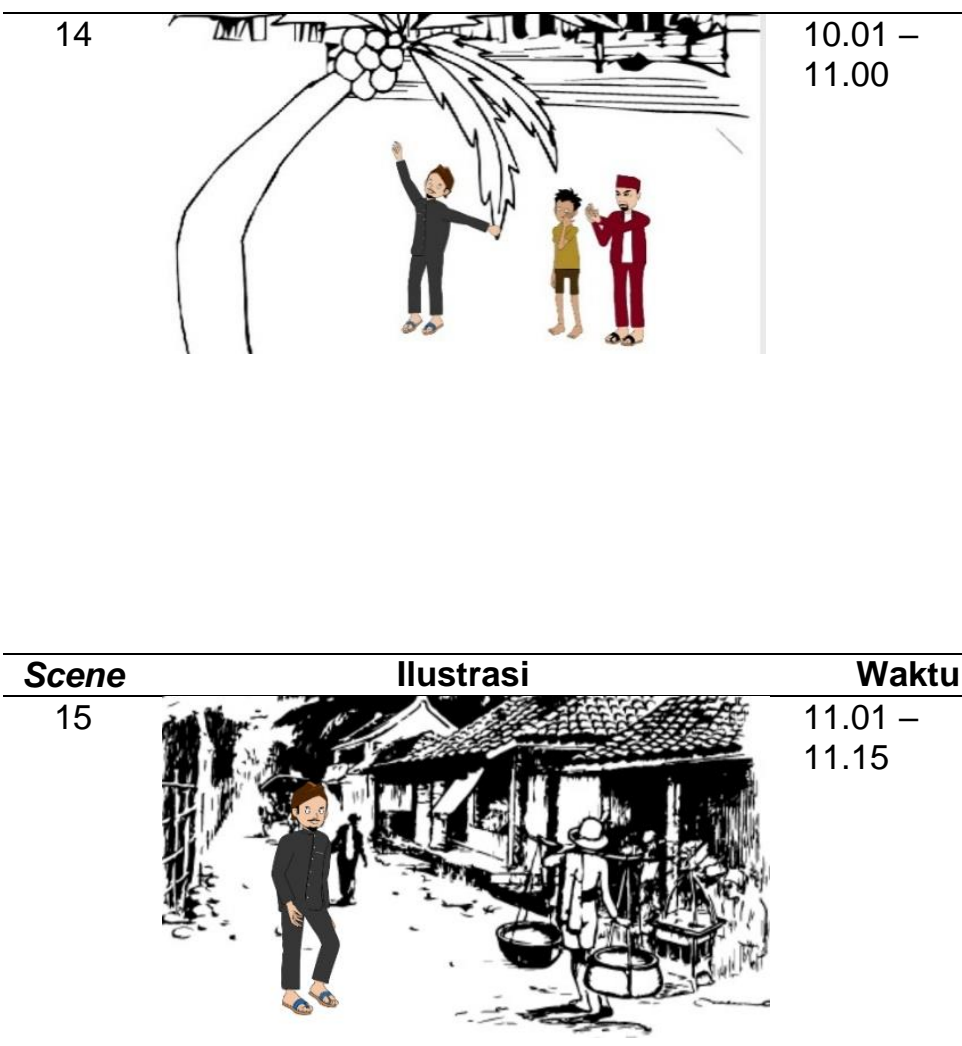

1. Kamera zoom in kemudian tilting

2. Ekspresi marah $\mathrm{Ki}$ Rogorunting yang disebabkan iri terhadap kehebatan $\mathrm{Ki}$ Singoprono

3. Ekspresi terkejut Ki Singoprono ketika di panggil oleh Ki Rogorunting dengan nada keras

4. Musik background tegang karena merupakan awal dari konflik Keterangan

1. Kamera diam

2. Musik background agak tegang

3. Efek suara hentakan kaki seperti berjalan

16

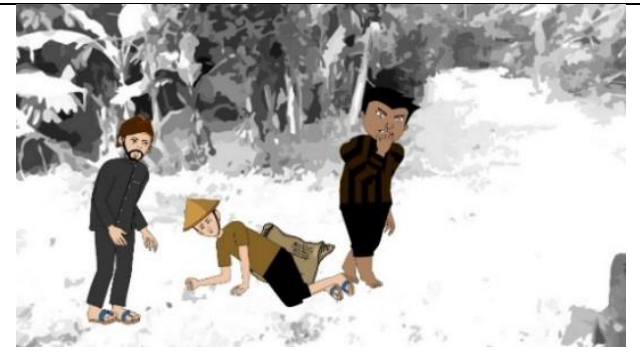

$11.16-$ 12.45
1. Kamera diam

2. Musik background tegang

3. Ekspresi kesal Ki Singoprono melihat Ajudan (Ki Rogorunting) menjatuhkan petani

4. Ekspresi kesakitan petani 
5. Ekspresi bahagia Ajudan (Ki Rogorunting)

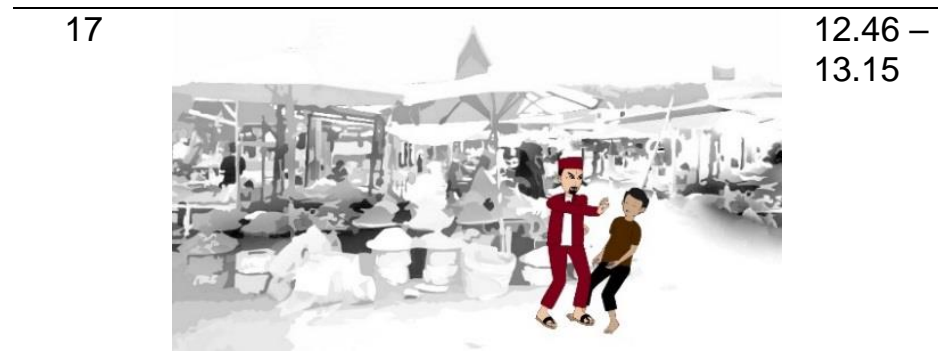

1. Kamera diam

Musik background tegang

3. Ekpresi kesal Ki Rogorunting setelah di permalukan $\mathrm{Ki}$ Singoprono

4. Ki Rogorunting memukul orang tanpa sebab

5. Ekspresi marah orang yang dipukul $\mathrm{Ki}$ Rogorunting

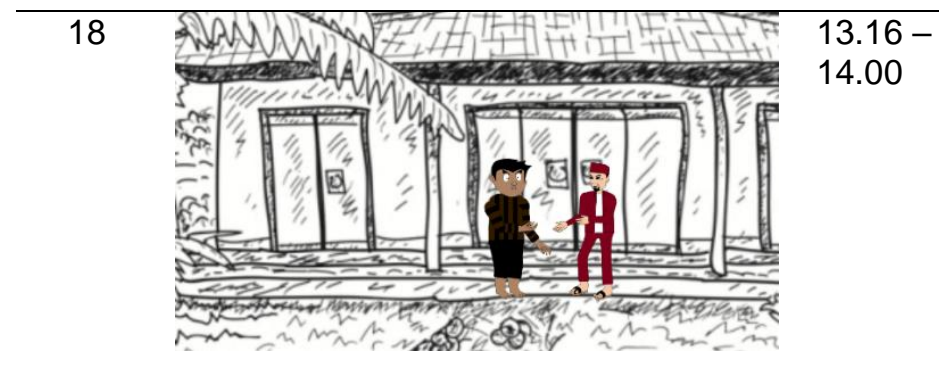

1. Suara Ajudan memanggil Ki Rogorunting ketika hendak masuk ke rumahnya

2. Musik background agak tegang kemudian ceria

3. Ekspresi licik Ajudan ketika memanas manasi Ki Rogorunting

4. Kamera zoom in

\section{9}

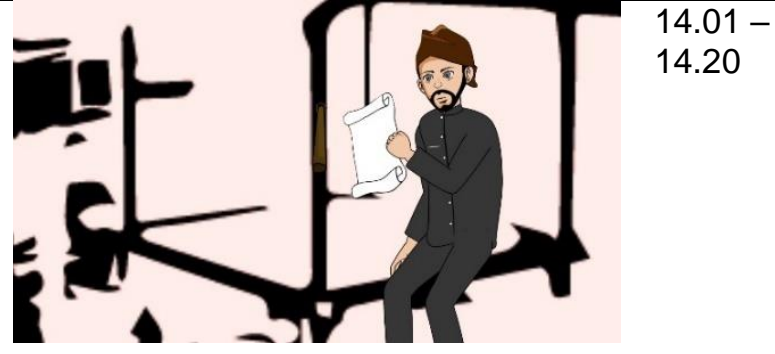

1. Musik background tegang

2. Ekspresi Ki Singoprono marah dan kesal ketika membaca surat berisi tentang istrinya diculik ki Rogoruntin

3. Kamera zoom in

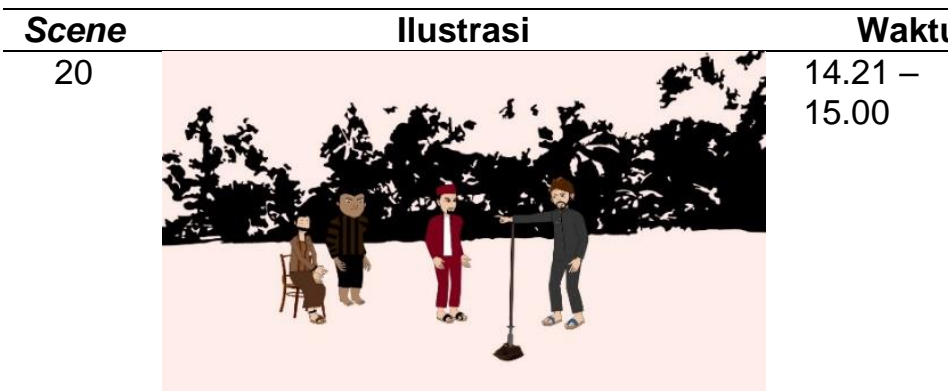

\section{Keterangan}

1. Kamera diam kemudian zoom in

2. Musik background tegang

3. Ekspresi ketawa ki Rogorunting dan Ajudannya 


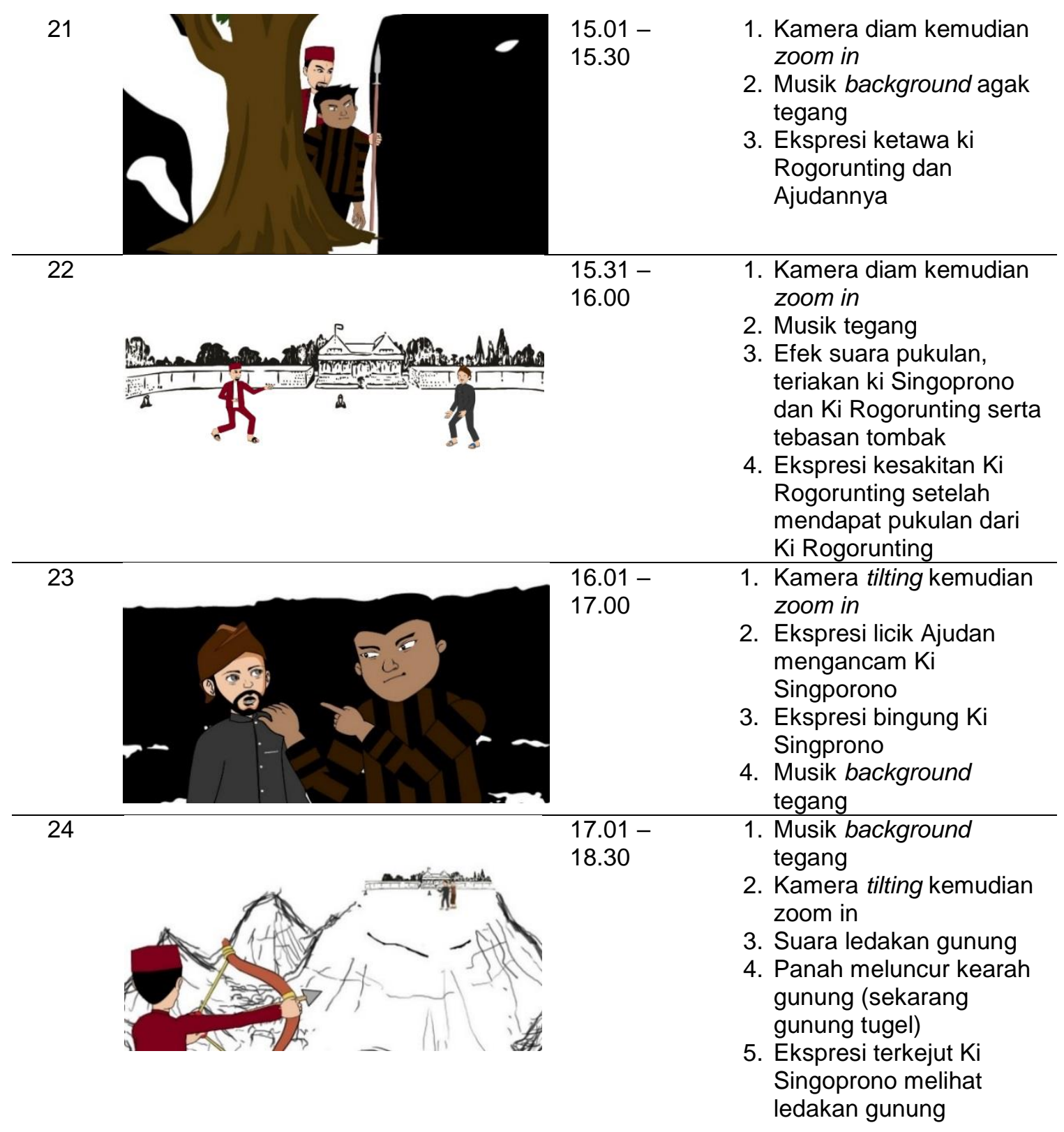


25

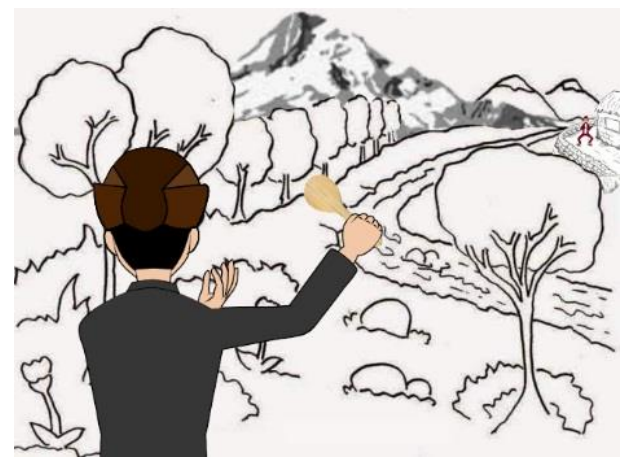

$18.31-$ 20.00
1. Kamera diam kemudian zoom in

2. Ekspresi kesal ki Singprono

3. Musik tegang

4. Ekspresi terkejut dan takut ki Rogorunting ketika melihat ki Singoprono melemparkan centong sakti ke arahnya (gunung madu)

5. Suara ledakan gunung madu

\subsection{Pengisi Suara}

Dalam Cerita "Legenda Gunung Tugel" terdapat 7 tokoh. Diantaranya Ki Singoprono, Ki Rogorunting, Ki Wongsoprono, Nyi Singoprono, Ajudan Ki Rogo Runting, petani dan pengemis. Adapun pengisi suara dari tokoh - tokoh tersebut adalah sebagai berikut :

1. Ki Singoprono

2. Ki Rogorunting

: Ady Setyo Nugroho

3. Ki Wongsoprono

: Ahzan Saiful Huda

4. Nyi Singoprono

: Ady Setyo Nugroho

5. Ajudan

: Afifah Tri Wardani

6. Petani

7. Pengemis

: Ahzan Saiful Huda

: Aditya Chrisna Mahendra

: Ahzan Saiful Huda

\subsection{Backsound}

Dalam pembuatan film "Legenda Gunung Tugel", penulis mengambil beberapa source sound dari audioblocks.org dan freesounds.org. Keduanya adalah website yang menyediakan efek suara dan musik yang disediakan secara gratis. Pengarang dari sound yang digunakan, penulis mencantumkan nya di dalam Credit Title.

\subsection{Rigging}

Rigging merupakan proses memberikan struktur tulang pada objek modelling untuk memudahkan penggerakan pada objek tersebut. Pada proses rigging film animasi 2D Legenda Gunung Tugel menggunakan software Moho Anime Studio Pro dengan menggunakan Bone Tool. Pada setiap modelling yang dibuat harus diberikan kerangka tulang agar mempermudah dalam proses penggerakannya. Berikut adalah contoh kerangka tulang dari modelling Ki Rogo Runting seperti pada Gambar 1.

Moho Anime Studio Bone Animation biasa digunakan untuk menggerakan tulang objek pada modelling. Untuk menggerakan tulang object menggunakan Manipulate Bones seperti ditunjukkan pada Gambar 2. 


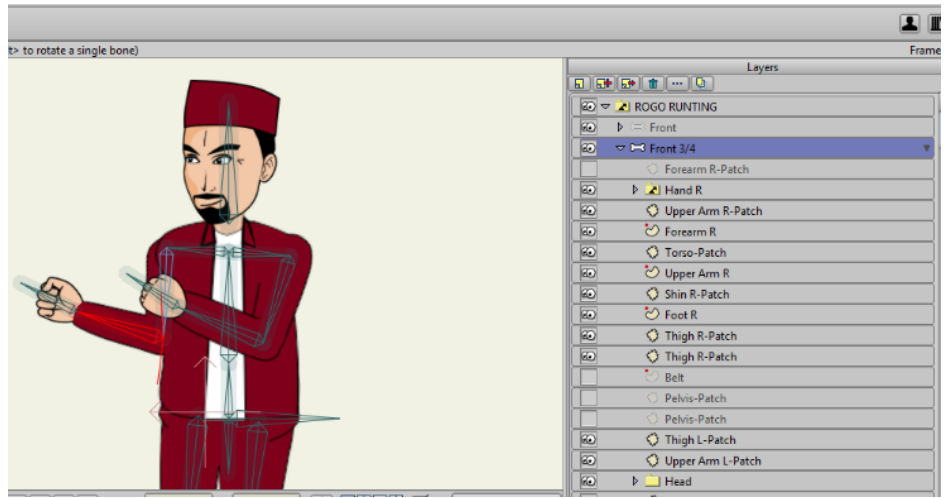

Gambar 1. Kerangka Tulang karakter Ki Rogo Runting

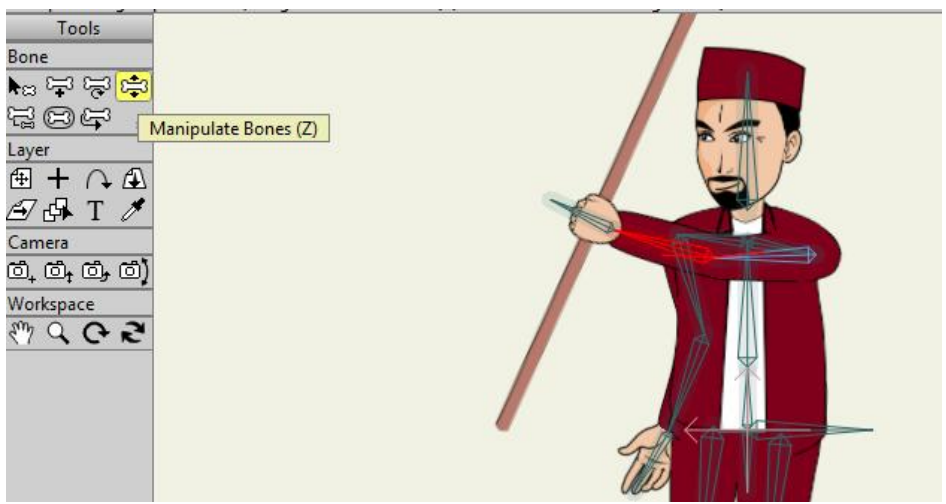

Gambar 2. Manipulate Bones melalui Moho Anime Studio

Apabila tulang tersebut sudah dianimasikan maka akan muncul tanda keyframe pada channels keyframe seperti Gambar 3.

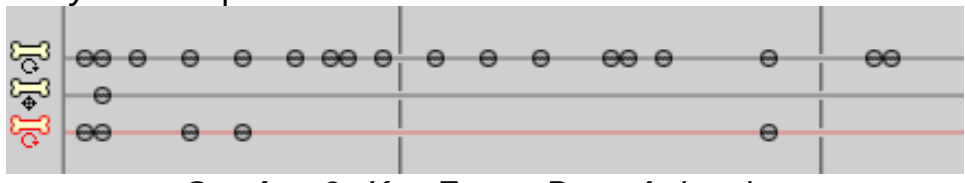

Gambar 3. Key Frame Bone Animation

\subsection{Hasil Pengujian Kuesioner}

Berdasarkan hasil dari kuisioner yang telah disebarkan, dapat disimpulkan bahwa terdapat 41 responden yang memberikan penilaian terhadap pembuatan film animasi "Legenda Gunung Tugel". Adapun gambar grafik hasil kuesioner dapat dilihat pada Gambar 4. Diperoleh dari presentase nilai dengan pemisalan poin $100=$ sangat setuju, 75 = setuju, 50 = cukup, 25 = kurang, sehingga nilai maksimal adalah 4100 (100x41), maka presentase nilai dari setiap pertanyaan adalah :
1. Modelling Baik
: $3275 / 4100 * 100 \%=79 \%$
2. Backsound Menarik : $3525 / 4100 * 100 \%=85 \%$
3. Visual Effect Menarik : $3150 / 4100 * 100 \%=76 \%$
4. Environment Baik : $3175 / 4100 * 100 \%=77 \%$

Berdasarkan hasil kuisioner diatas dapat disimpulkan bahwa dari 41 responden rata rata mengatakan film animasi "Legenda Gunung Tugel" yang telah dibuat dinilai sangat 
baik dalam aspek modelling, backsound, visual effect dan environment. Tampilan poster film animasi Gunung Tugel seperti ditunjukkan pada Gambar 5.

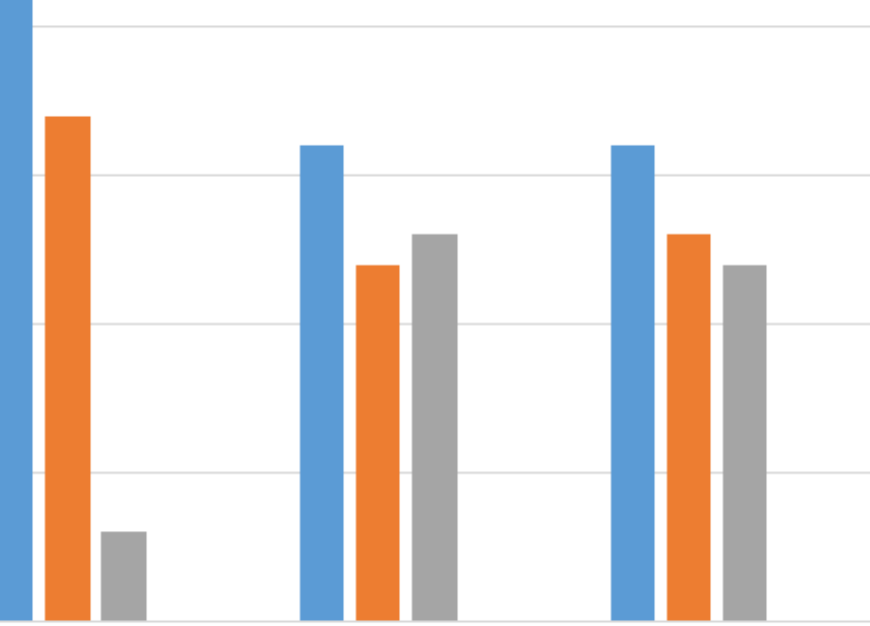

0

Backsound Menarik

Visual Effect Menarik

Environment Baik

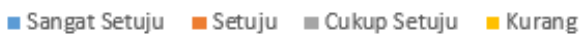

Gambar 4. Grafik hasil kuesioner

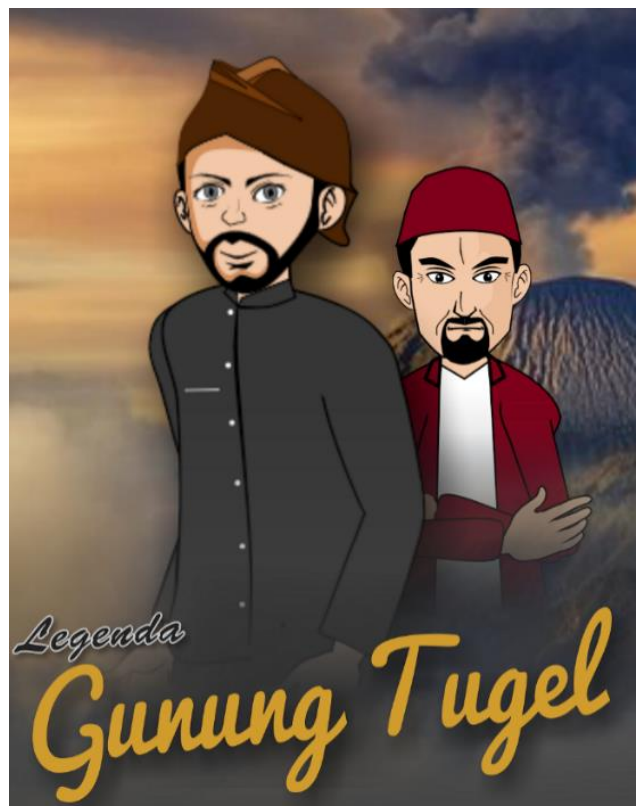

Gambar 5. Hasil poster film animasi 2D Gunung Tugel 


\section{KESIMPULAN}

Dalam pengembangan produk film animasi ini dapat disebutkan beberapa kesimpulan, yaitu telah berhasil dibuat film animasi berbasis dua dimensi dengan judul "Legenda Gunung Tugel". Cerita "Legenda Gunung Tugel” dirender dengan spesifikasi ekstensi .mp4, dengan resolusi video 1280 x 720, serta berdurasi 18 menit 54 detik. Hasil penilaian masyarakat mengenai film animasi 2D tersebut mendapat nilai yang baik, meliputi aspek modelling karakter, audio, visual effect dan environtment yang disajikan pada film tersebut.

\section{DAFTAR PUSTAKA}

[1] Adinata, Barnas Danu. 2010. Virtualisasi Legenda Roro Jonggrang Menggunakan Blender. Depok : Universitas Indonesia

[2] Wahyu, Veronica. 2013. Perancangan Film Kartun 2D "Legenda Danau Toba". Yogyakarta : AMIKOM Yogyakarta

[3] Syafrudin, Chabib. 2013. Pembuatan Film Animasi Pendek "Dahsyatnya Sedekah" Berbasis Multimedia Menggunakan Teknik 2D Hybrid animation Dengan Pemanfaatan Graphic. Yogyakarta : Universitas Ahmad Dahlan

[4] Fukaren, Jonatahab. 2015. Perancangan Video Motivasi Animasi 2D untuk Buku Terlaris di Dunia “Who Moved My Cheese?". Medan : STMIK TIME

[5] Kuswan, Dani. 2007. Animasi 2D 3 Menit Belajar IImu Pengetahuan Umum. Bandung : Universitas Widyatama

[6] Djalle, Zaharuddin G. 2007. The Making of 3D Animation Movie. Bandung: Penerbit Informatika.

[7] Murdock, Kelly L. 2008. Anime Studio: The Official Guide. USA: Course Technology. 